\title{
EFFECT OF BIOACTIVE FROM Phyllathus niruri ON BEFORE AND DURING INFECTION OF Plasmodium berghei IN MICE
}

Tri Wulandari Kesetyaningsih and Sri Sundari

\author{
Department of Parasitology, Faculty of Medicine and Health Science, \\ Universitas Muhammadiyah Yogyakarta \\ Jl. Lingkar Selatan, Tamantirto, Kasihan, Bantul, Yogyakarta \\ Email: kesetyaningsih@yahoo.com
}

\section{INTRODUCTION}

Malaria is a health problem in many countries, including Indonesia. The problem is difficult to be solved due to resistance on many antimalarial drugs. Therefore, alternative treatment is needed to be developed. Phyllanthus niruribefore infection can increase the activity of macrophages in mice were infected by Plasmodium berghei but there has been no research after infection. This study aims to compare the effect of $P$. niruribetween before and after infection with malaria.

\section{MATERIALS AND METHODS}

Design of research is posttest only control group. The subject are mice strains Swiss, males, 5 weeks old, weighing 20-25 g, have never been infected by Plasmodium. Independent variable: prophylaxis treatment by $P$. niruri extract $(\mathrm{P} 1)$; curative treatment by $P$. niruri extract (P2); chloroquine $\left(\mathrm{K}_{+}\right)$; untreated (K-). Dependent variable: parasitemia, spleen and brain histologic.

Twenty mice were divided into four groups so each group consist of five mice. After five days of acclimatization, mice were infected by $P$. berghei in $0.1 \mathrm{ml}$ dose contains $1 \times 10^{6} \mathrm{P}$. berghei i.p. (Pedroni et al., 2006). Curative treatment was done 5 days after 24 hours infection while prophylaxis was done 5 days before infection. The dosage of Chloroquine is $2 \mathrm{mg} /$ $\mathrm{kg} \mathrm{BW}, 2 \mathrm{mg} / \mathrm{kg} \mathrm{BW}$ and $1 \mathrm{mg} / \mathrm{kg} \mathrm{BW}$ respectively in 3 days. The dose of Phyllanthus niruri is $1,3 \mathrm{gram} /$ day (Periyanayagam et al., 2008).

Observation of parasitaemia was done every day for 5 days after infection. It was conducted by examination to the blood smears that colored by Giemsa's. The last day of the study all the mice were sacrificed, taken for spleen and brain histopathological preparation. The difference of parasitemia density among study groups were analyzed by one way anova and histologics appearence were analyzed by nonparametrics analysis Kruskall-Wallis.

\section{RESULTS AND DISCUSSION}

Result of parasitaemia examination during 1-6 days after infection is presented in Figure 1.

One way ANOVA shows that there is a significant difference on parasitaemia among all study groups $\left(F_{\text {calculte }}=19,634>F_{\text {table }}=3,34\right)$. The analysis continued DMRT (Duncan's Multiple Range Test). The result was presented in Table 1. It shows that treatment by $P$. niruri effective to suppress the growth of parasite in blood cell. 


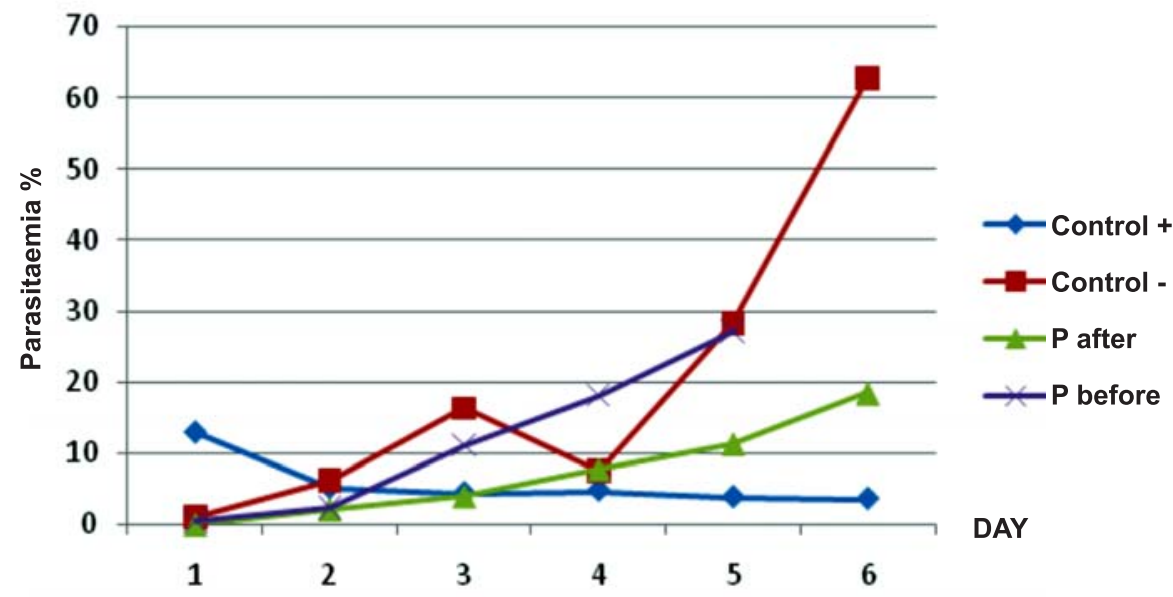

Figure 1. Average of parasitaemia after infection in all study groups

Table 1. Significancy of difference among the study groups

\begin{tabular}{ll}
\hline Between Groups & P value \\
\hline K+ (positive control) - K- (negative control) & $0,000^{*}$ \\
K+ (positive control) - P2 (after infection) & 0,773 \\
K+ (positive control) - P1 (before infection) & 0,797 \\
K- (negative control) - P2 (after infection) & $0,000^{*}$ \\
K- (negative control) - P1 (before infection) & $0,000^{*}$ \\
P2 (after infection) - P1 (before infection) & 0,974 \\
\hline
\end{tabular}

Histology's appearance of spleen and brain examination was conducted to know the influence of Phyllanthus niruritowards immune response against malaria. It assumed granting $P$. nirurican promote macrophages activity in spleen.

Table 2. Histological appearance of spleen and brain tissue at $7^{\text {th }}$ day after P. berghei infection in all study groups

\begin{tabular}{|c|c|c|c|c|}
\hline Tissue & K- (untreated) & $\mathrm{K}+$ (Chloroquine) & $\begin{array}{l}\text { P1 ( } P \text {. niruri before } \\
\text { infection) }\end{array}$ & $\begin{array}{l}\text { P2 (P. niruri after } \\
\text { infection) }\end{array}$ \\
\hline Spleen & $\mathrm{M}<; \mathrm{R}$ & $M>$ & $M>$ & $\mathrm{M}>$ \\
\hline Brain & - & - & - & M \\
\hline
\end{tabular}

Note: $M=$ macrophage; <=slightly; >=many; $\mathrm{R}=$ inflammation cell infiltration

The histological study shows that there were inflammation reaction in spleen tissue in all groups of study proven by increasing the number of macrophage (Table 2). In untreated group there was a tendency in other inflammatory cells in addition to macrophages. While in brain tissue, macrophages only found in P2 ( $P$. niruriafter infection).

According to Kaur et al., (2005) and Sandhya et al., (2006), Phyllanthus niruri contains derivate polyphenol, including tannin and gallic acid. Although the mechanism on the activity of this extract has not been examined, some of these metabolites are believed to have the effect of antiplasmodial. The mechanism is suggested through increasing oxidation of red blood cells and inhibition of the synthesis of protein. Possible natural antiplasmodia in the 
extract of $P$. emblica, T. bellerica and T. chebula. is gallic acid (Rakotondramanana et al., 2007; Ramanandraibe et al., 2008) and tannin (Reddy et al., 2007; Dell'Agli et al., 2009).

\section{REFERENCES}

Dell'Agli, M., G.V. Galli, Y. Corbett, D. Taramelli, L. Lucantoni, A. Habluetzel. 2009. Antiplasmodial activity of Punica granatum L. fruit rind. J Ethnopharmacol 125: 27985.

Kaur, S., H. Michael, S. Arora, P.L. Harkonen, S. Kumar. 2005. The in vitro cytotoxic and apoptotic activity of Triphala-an Indian herbal drug. J Ethnopharmaco/97: 15-20.

Pedroni, H.C, C.C. Bettoni, S.U. Spalding, and T.D. Costa. 2006. Plasmodium berghei Development an irreversible experimental malaria model in Wistar rat. Exp. Parasitolo. http://www.anopheles.org/show abstract.php?paid=16494867. Accessed 10 April 2010

Periyanayagam, K., K.N. Devi, L. Suseela, A. Um, and M. Ismail. 2008. Invivo antimalarial activity of leaves of Plectranthus amboinicus L. spreng on Plasmodium berghei Yoelli. J.Commun Dis. 40:121-5

Rakotondramanana, D.L., M. Delomenede, M. Baltas, H. Duran, F. Bedos-Belval, P. Rasoanaivo. 2007. Synthesis of ferulic ester dimers, functionalisation and biological evaluation as potential antiatherogenic and antiplasmodial agents. Bioorg Med Chem. 15: $6018-26$

Ramanandraibe, V., P. Grellier, M.T. Martin, A. Deville, R. Joyeau, D. Ramanitrahasimbola. 2008. Antiplasmodial phenolic compounds from Piptadenia pervillei. Planta Med. 74: 417-21.

Reddy, M.K., S.K. Gupta, M.R. Jacob, S.I. Khan, D. Ferreira. 2007. Antioxidant, antimalarial and antimicrobial activities of tannin-rich fractions, ellagitannins and phenolic acids from Punica granatum L. Planta Med. 73: 461-7.

Sandhya, T., and K.P. Mishra. 2006. Cytotoxic response of breast cancer cell lines, MCF 7 and T $47 \mathrm{D}$ to triphala and its modification by antioxidants. Cancer Lett. 238: 304-13. 